Historic, archived document

Do not assume content reflects current scientific knowledge, policies, or practices. 

cop.2

\section{Detection of Hidden Insect Infestations in Wheat by Infrared Carbon Dioxide Gas Analysis}

U.S. Department of Agriculture Agricultural Research Service Advances in Agricultural Technology • AAT-S-26/July 1982 
Trade names are used in this publication solely for the purpose of providing specific information. Mention of a trade name does not constitute a guarantee or warranty of the product by the U.S. Department of Agriculture or an endorsement by the Department over other products not mentioned.

This publication is available from the Stored-Product Insects Research and Development Laboratory, P.O. Box 22909, Savannah, Ga. 31403.

Agricultural Research Service, Advances in Agricultural Technology, Southern Series, No. 26 , July 1982.

Published by Agricultural Research Service (Southern Region), U.S. Department of Agriculture, P.O. Box 53326, New Orleans, La. 70153. 
Page

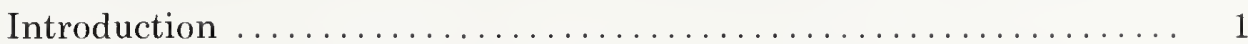

Operation of the detection system $\ldots \ldots \ldots \ldots \ldots \ldots \ldots \ldots \ldots \ldots \ldots$

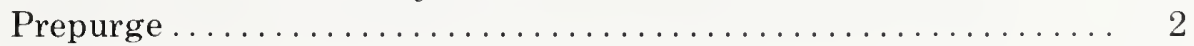

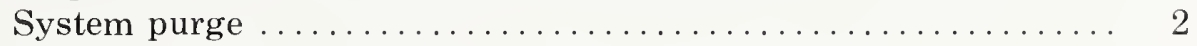

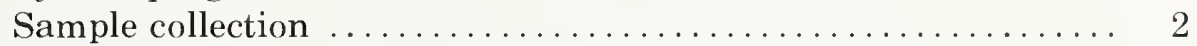

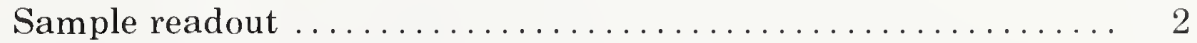

Materials and methods ........................... 3

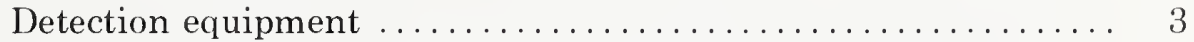

Test procedure ................................ 4

Insect rearing ............................... 4

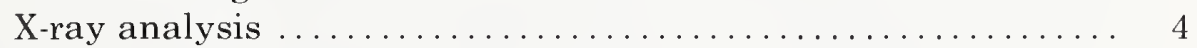

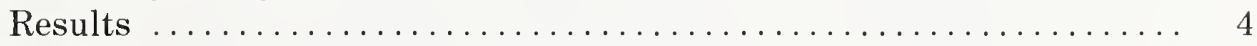

Standard versus new test procedures ............... 4

Equipment performance .......................... 4

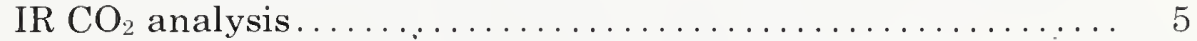

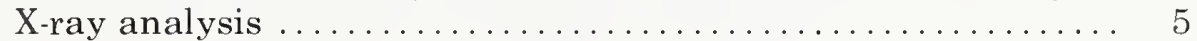

Insect rearing .............................. 7

Discussion ................................... 7

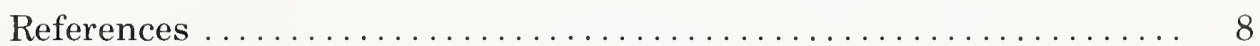

Appendix.-Supplier names and addresses............. 8

\section{ILLUSTRATION}

Fig.

1. Components of insect-detection system

\section{TABLES}

1. IR $\mathrm{CO}_{2}$ analysis of hard red winter wheat for hidden insect infesta-

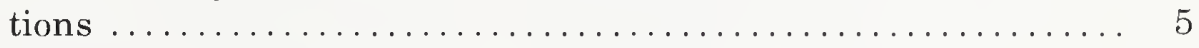

2. X-ray analysis of subsamples .................... 6

3. Visual inspection of samples after 9-week rearing period . . . . 6

4. Insect species identified in wheat samples $\ldots \ldots \ldots \ldots \ldots \ldots \ldots$ 



\title{
Detection of Hidden Insect Infestations in Wheat by Infrared Carbon Dioxide Gas Analysis
}

\author{
By William A. Bruce, ${ }^{1}$ M. Wayne Street, ${ }^{2}$ Randall C. Semper, ${ }^{3}$ and David Fulk ${ }^{4}$
}

\begin{abstract}
A method for the detection of hidden insects by means of infrared $\mathrm{CO}_{2}$ gas analysis that measures insect-produced $\mathrm{CO}_{2}$ given off during respiration was tested under limited field conditions. The 2-year study has demonstrated that this method is significantly better than present routine inspection procedures at detecting hidden insects. Of the 459 samples tested $96 \%$ were eventually found to be infested. Only $11 \%$ of the infestations were detected with current procedures; but IR $\mathrm{CO}_{2}$ analysis detected $81 \%$. Index terms: grain insects, grain inspection, insect detection, inspection (agricultural products), wheat insects, wheat inspection.
\end{abstract}

\section{INTRODUCTION}

The need to detect hidden insect infestations in agricultural commodities throughout the marketing channel has long been recognized by consumers, regulatory agencies, research scientists, and administrators. But destruction and damage caused by insects to food and food ingredients have continued to increase. Growing pressure for increased efficiency of yield and protection from insect damage have intensified the need for detecting this kind of infestation. Early detection of hidden insects is also important in agricultural inspections made

\footnotetext{
'Research entomologist, Stored-Product Insects Research and Development Laboratory, Agricultural Research Service, U.S. Department of Agriculture, P.O. Box 22909, Savannah, Ga. 31403.

${ }^{2}$ Research physicist, retired, Stored-Product Insects Research and Development Laboratory.

:Management analyst, Inspection Division, Federal Grain Inspection Service, U.S. Department of Agriculture, Washington, D. C. 20250.

${ }^{4}$ Chief, Marketing Standards Branch, Standardization Division, Federal Grain Inspection Service, U.S. Department of Agriculture, Grandview, Mo. 64030.
}

for quality control, quarantine, and other purposes. Approaches to detection have embodied several physical, chemical, and biological principles (see, for example, Adams et al. 1954, Milner 1958, Dennis and Decker 1962, Bruce et al. 1978, and Bruce and Street 1979). Detection techniques can be either active or passive. Active techniques require that something be added to the substance being tested. Passive techniques depend only on naturally occurring outputs such as infrared energy radiated by the insects, sounds produced by feeding, or gas produced by insect metabolism or respiration (Bruce and Street 1974).

Currently, one method being investigated for insect detection purposes is infrared (IR) $\mathrm{CO}_{2}$ analysis. This system has been described in detail previously from the physical (Bruce and Street 1974, Street and Bruce 1976b) and biological (Bruce and Street 1975, Street and Bruce 1976a) aspects. The advantages of this system over other methods are speed, reliability, repeatability, and sensitivity.

To determine how effective IR $\mathrm{CO}_{2}$ gas analysis is in detecting hidden insect 
infestations from field-collected samples of wheat, a cooperative test involving the U.S. Federal Grain Inspection Service (FGIS) and U.S. Agricultural Research Service (ARS) was established. The objectives of this study were to: evaluate the system's effectiveness in detecting hidden insect infestations, determine if dockage alters the effectiveness of the detection system, and determine if $\mathrm{IR} \mathrm{CO}_{2}$ analysis systems placed in Houston, Tex., and Savannah, Ga., would yield similar results.

\section{OPERATION \\ OF THE DETECTION SYSTEM}

Operation of the insect-detection system (fig. 1) may be conveniently divided into four steps: prepurge, system purge, sample collection, and sample readout.

\section{Prepurge}

The prepurge is used to flush accumulated gases out of a sample-filled test chamber just before its connection to the detection apparatus. If a sample of unknown quality has been left unattended for any length of time, it may contain entrained $\mathrm{CO}_{2}$ from insects in the sample or from slow respiration of the sample itself or of fungi, particularly at elevated moisture contents. So the prepurge simply flushes out any accumulated $\mathrm{CO}_{2}$ and reduces the time required for online equilibration during the next step, system purge. In actual practice, prepurging can be arranged so that, as each sample is being tested, the next oncoming sample is being prepurged.

\section{System Purge}

The system uses an interrupted-flow principle to detect deviation from an equilibrium baseline. This baseline is established during system purge. Immediately after the test chamber is connected to the system, the carrier gas is allowed to flow until the differential output from the $\mathrm{CO}_{2}$ analyzer stabilizes, indicating equilibrium, which is generally zero except when infestations are heavy (Street and Bruce 1976b).

\section{Sample Collection}

During sample collection, carrier gas flow is cut off and the analyzer and sample system sealed by inline valves to permit buildup of the insect-produced $\mathrm{CO}_{2}$ in the test chamber. At the onset of the sample-collection interval, the reference cell, test chamber, and sample cell contain equal concentrations of $\mathrm{CO}_{2}$ because equilibrium has been reached during the preceding system purge. As soon as carrier gas flow ceases, the following occur: In the reference cell, the nominal $\mathrm{CO}_{2}$ concentration remains essentially constant since the carrier gas is trapped and nonflowing; in the test chamber, the $\mathrm{CO}_{2}$ concentration begins to rise above the equilibrium value because of the addition of the insect-produced $\mathrm{CO}_{2}$; in the sample cell, a condition similar to that in the reference cell exists - the trapped carrier gas is nonflowing and has the equilibrium concentration of $\mathrm{CO}_{2}$ reached during system purge. Since there is no flow, any diffusion of $\mathrm{CO}_{2}$ beyond the boundaries of the test chamber should occur in both directions and, because of system symmetry, produce minimal differential imbalance between the analyzer reference and sample cells. No discernible imbalance caused by $\mathrm{CO}_{2}$ diffusion has been observed in the prototype system. But, should it occur, it could be eliminated simply by adding valves on each side of the test chamber. At the end of the sample-collection interval, the test chamber will contain a concentration of $\mathrm{CO}_{2}$ that is higher than that in the analyzer reference and sample cells.

\section{Sample Readout}

The valves are opened to unseal the system, and the airflow is restarted. The higher concentration bolus of $\mathrm{CO}_{2}$ moves out of the test chamber and through the sample cell of the IR analyzer. The resulting imbalance between the $\mathrm{CO}_{2}$ concentration in the two optical cells of the IR analyzer generates a signal that is displayed as a peak on the chart recorder. After the bolus has passed through the system, equilibrium is again reached where conditions are stable among the reference cell, test chamber, and sample cell. As soon as equilibrium is reached, 
sample collection and sample readout may be repeated as often as desired.

\section{MATERIALS AND METHODS}

\section{DETECTION EQUIPMENT}

\section{Houston}

The equipment for the insect-detection system as described consists basically of an IR $\mathrm{CO}_{2}$ analyzer, a series of solenoid valves and timer to control airflow, a small pump, a test chamber, and a signal readout device (meter or strip-chart recorder). The systems constructed and supplied by ARS to FGIS, for evaluation, were two portable, self-contained laboratory units for use at the port of Houston, Tex. Each unit consisted of a Mine Safety Appliances (MSA; see appendix for a list of supplier names and addresses) Luft-type differential IR $\mathrm{CO}_{2}$ analyzer with a sensitivity of $0-100 \mathrm{p} / \mathrm{m}$ (parts per million) $\mathrm{CO}_{2}$, two Industrial Timer Corp. collect-readout timers, two Dwyer airflow meters, a Universal Electric Co. 1.5-amp pump, an E\&K 8-inch stripchart recorder, and quick-disconnect ports for test chamber hookup. Technicon Instruments Corp. placed a detection system in Houston that was similar to this configuration but different in several features. Their system used a Horiba Instruments PIR-2000 IR $\mathrm{CO}_{2}$ gas analyzer with a high sensitivity range of $0-25 \mathrm{p} / \mathrm{m} \mathrm{CO}_{2}$. A total of three test chambers allowed samples to be analyzed sequentially and simultaneously

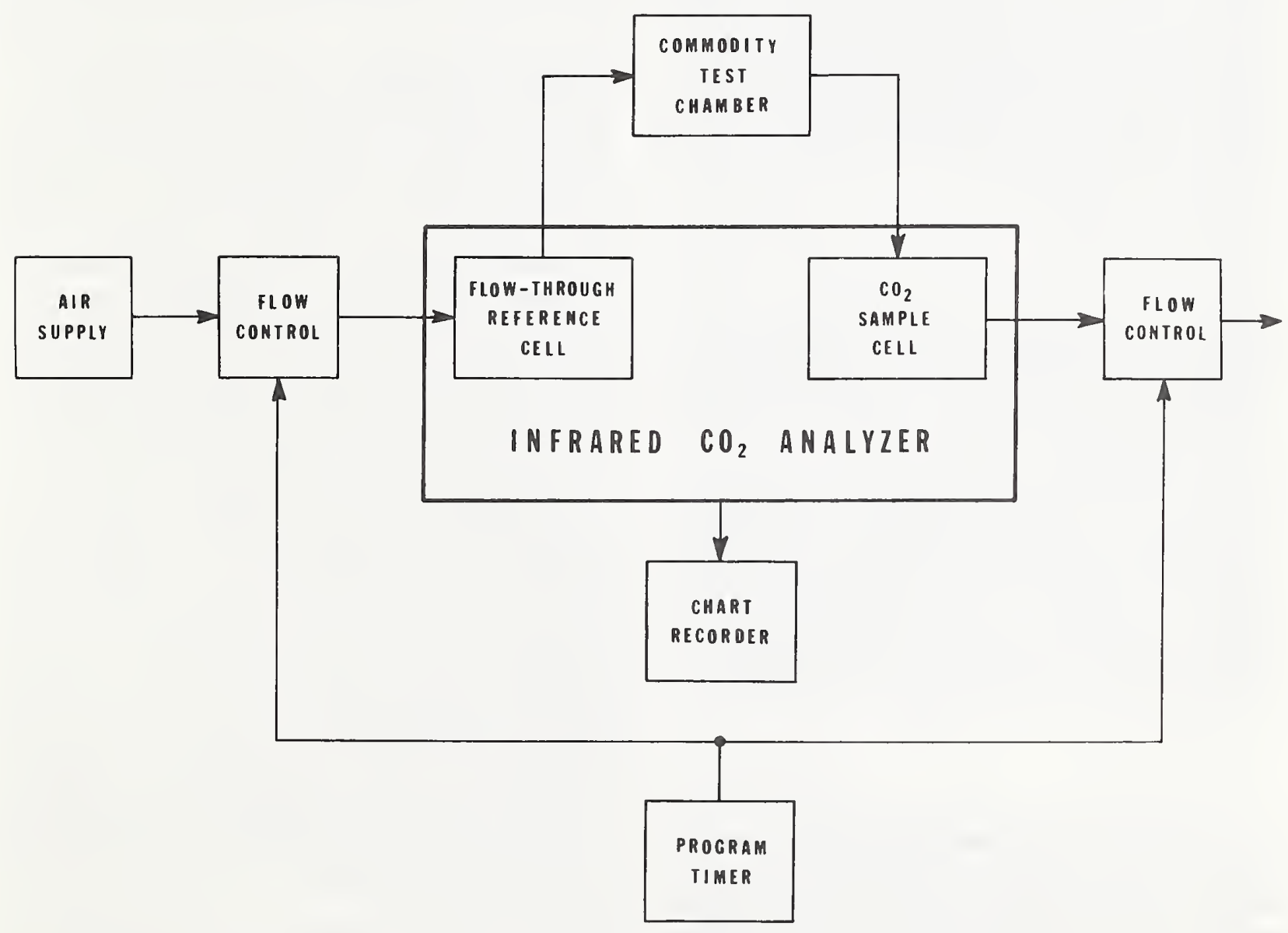

FIGURE 1.-Components of insect-detection system. (Source: Street and Bruce 1976b.) 
through prepurge, $\mathrm{CO}_{2}$-sample collection, and $\mathrm{CO}_{2}$-sample readout. A gas $\left(\mathrm{CO}_{2}\right)$ calibration unit was incorporated to insure accurate and rapid calibration of the system.

\section{Savannah}

The Savannah system used a Beckman Instruments Model 865 and a Horiba PIR-2000 IR $\mathrm{CO}_{2}$ gas analyzer. All remaining components were essentially the same as the Houston MSA system except that they were notinstalled in a cabinet but were arranged on a bench top to facilitate operating and research procedures.

\section{Test Procedure}

The test proced ure of the insect-detection system was designed by R. C. Semper. The tests were conducted at the FGIS Houston field office, and at the ARS Stored-Product Insects Research and Development Laboratory in Savannah. The test proced ure had three stages: sample collection of hard red winter wheat at Houston, testing at the Houston field office, and testing at Savannah.

\section{INSECT REARING}

Each wheat sample consisted of four subsamples: A, B, A dockage, and B dockage. After the subsamples were analyzed for $\mathrm{CO}_{2}$, each was placed in a quart jar and then taken to a holding room maintained at about $27^{\circ} \mathrm{C}$ and $80 \%$ relative humidity for at least 9 weeks. Care was taken to insure that no insect contamination occurred during the handling process. After the appropriate rearing period had elapsed, each sample was again observed for insects, alive or dead, analyzed for $\mathrm{CO}_{2}$, and X-rayed when required. Then, all samples were discarded.

\section{X-RAY AnALYSIS}

A Hewlett-Packard Faxitron model 43804N was used for X-ray inspection. Exposure time and operating voltage can be varied for optimum results. The wheat for X-ray was first spread in a monolayer directly onto Kodak Radioprint TP6 paper and then placed into the $\mathrm{X}$-ray unit at $30 \mathrm{kV}^{\top}$ for 60 seconds. After exposure to X-rays, the Radioprint TP6 paper was developed in a Kodak Ektachrome automatic processor. The radiograph was visually inspected for the presence of insects. Samples designated for X-ray analysis were those that had a positive $\mathrm{CO}_{2}$ reading but had no adult insects emerge after the 9 -week rearing period. Samples without a positive $\mathrm{CO}_{2}$ reading and with no adult emergence were X-rayed to check for extremely low levels of infestation or infestations of insects that may have died before sample collection.

\section{RESULTS}

Standard Versus New

Test Procedures

The results obtained using $\mathrm{IR} \mathrm{CO}_{2}$ analysis for detection of hidden insect infestations indicate the potential for use of this method in routine grain inspection. Using current FGIS standard procedures to determine the presence of insects in a particular sample gave the following results: (1) 6 infestations were noted visually in 597 samples $(1.0 \%)$ at the grain-loading facility (of 600 samples, Nos. 22, 23, and 126 were missing); (2) 59 more infestations were noted visually by Houston personnel in the 597 samples $(10 \%)$. Therefore, the procedures normally used by FGIS personnel to determine the presence of at least 2 live adult insects per sample accounted for 65 of 597 total samples or $11 \%$. The testing done at Houston and Savannah showed that, of 459 samples received (Nos. 142-600), 440 (96\%) were infested. This percentage includes all insect life stages, and results are derived from visual, IR $\mathrm{CO}_{2}$, rearing, and $\mathrm{X}$-ray analysis of samples. Current FGIS standards are restricted to identifying only live adults before a sample can be defined as weevily. But, while the methods studied include procedures not allowable under current inspection routines, these data show that rates of insect infestation in U.S. hard red winter wheat processed for export through the port of Houston during the study period were considerably higher than reported.

\section{Equipment Performance}

The Beckman $865 \mathrm{CO}_{2}$ analyzer at Savannah malfunctioned during analysis of samples 
Table 1.-IR $\mathrm{CO}_{2}$ analysis of hard red winter wheat for hidden insect infestations

\begin{tabular}{|c|c|c|c|c|c|c|c|c|c|c|c|c|}
\hline \multirow{3}{*}{ Location } & \multirow{3}{*}{$\begin{array}{c}\text { IR } \mathrm{CO}_{2} \\
\text { detection } \\
\text { system }\end{array}$} & \multirow{3}{*}{$\begin{array}{c}\text { Total } \\
\text { No. } \\
\text { samples }\end{array}$} & \multicolumn{5}{|c|}{ Samples indicated positive } & \multicolumn{5}{|c|}{ Samples not indicated positive } \\
\hline & & & \multirow{2}{*}{$\begin{array}{l}\text { Total } \\
\text { No. }\end{array}$} & \multirow{2}{*}{ Emerged } & \multicolumn{3}{|c|}{ X-ray } & \multirow{2}{*}{$\begin{array}{c}\text { Total } \\
\text { No. }\end{array}$} & \multirow{2}{*}{ Emerged } & \multicolumn{3}{|c|}{ X-ray } \\
\hline & & & & & + & - & $?$ & & & + & - & $?$ \\
\hline Houston & MSA & 459 & ${ }^{1} 146$ & 127 & 13 & .. & . & 2313 & 237 & 63 & 1 & 3 \\
\hline Houston & $\begin{array}{c}\text { Technicon } \\
\text { Horiba. }\end{array}$ & 228 & 193 & 171 & 22 & .. & . & 335 & 32 & 2 & . & . \\
\hline Savannah. & Horiba .... & 459 & 373 & 316 & 52 & 3 & 2 & ${ }^{2} 86$ & 21 & 51 & 2 & 3 \\
\hline
\end{tabular}

12 samples positive, nothing found, no X-ray.

29 samples not positive, nothing emerged, no X-ray.

${ }^{3} 1$ sample not positive, nothing found, no X-ray.

1-141, so only samples $142-600$ were used for comparative purposes unless otherwise noted. These samples were inspected with the Horiba PIR-2000 IR $\mathrm{CO}_{2}$ analyzer. Because its sensitivity $(0-25 \mathrm{p} / \mathrm{m})$ was four times that of the MSA units in Houston, the Horiba was used as the standard.

From all indications, the equipment, including IR $\mathrm{CO}_{2}$ analyzers (except Beckman 865), timers, solenoid valves, flowmeters, etc., performed extremely well. Most problems that did arise involved dirty IR and air filters, analyzer calibration, and other conditions that could be resolved with normal maintenance procedures. FGIS and ARS personnel reported that they experienced no difficulty with the system operation and inspection procedure, though occasionally a question would arise concerning analyzer stability or electrical background noise levels and the need for analyzer calibration.

Because of better range of sensitivity, it was anticipated that the systems using Horiba analyzers would detect more hidden insect infestations. Comparison of the results (table 1) of the three systems shows that this was so. Although the number of samples analyzed with the Houston Technicon (Horiba) was about one-half that analyzed by the Savannah Horiba, the results were very similar. The Houston Technicon system gave a positive indication of insects $85 \%$ of the time and the Savannah Horiba system $81 \%$. Actual emergence from these hidden, positive infestations was $89 \%$ (Houston Technicon) and $85 \%$ (Savannah Horiba). But the Houston MSA system indicated a positive infestation only $32 \%$ of the time and gave no indication of infestation $68 \%$ of the time. And, of the 313 samples not indicated as infested, $76 \%$ eventually produced an infestation.
IR $\mathrm{CO}_{2}$ Analysis

The IR $\mathrm{CO}_{2}$ analysis of grain samples used three different system configurations (Houston MSA, Houston Technicon (Horiba), Savannah Horiba) and four different analyzers. Savannah experienced problems with electrical noise early in the test with the Beckman 865; Houston MSA instrument No. 1 had some slight electrical noise throughout the test and at one point was reported to have excessive electrical noise probably caused by a dirty IR filter. Therefore, all data used from Houston MSA are based on instrument No. 2. Houston Technicon, brought online at sample No. 347, experienced some minor problems that were corrected by Technicon personnel. During the repair period, 26 samples were inspected only with the Houston MSA equipment.

IR $\mathrm{CO}_{2}$ analysis data (Savannah Horiba) show that, of 459 samples (Nos. 142-600) tested, 373 or $81 \%$ were suspect (positive or suspected infestation); after the 9 -week rearing period an infestation was observed visually in 316 of these samples (table 1). X-ray analysis revealed that $52(91 \%)$ of the 57 suspect samples that had no emergence after the rearing period were infested, 2 were suspect, and 3 were negative.

\section{X-RAY ANALYSIS}

A total of 503 subsamples (dockage A, B; wheat $\mathrm{A}, \mathrm{B}$ ) representing 217 samples were subjected to X-ray analysis (table 2). About 4,000 radiographs were analyzed to see if they supported the findings of IR $\mathrm{CO}_{2}$ analysis. Analysis of the dockage material was particularly difficult and time consuming because there were differences in the kinds of seeds present 
Table 2.-X-ray analysis of subsamples

\begin{tabular}{|c|c|c|c|c|}
\hline \multirow{2}{*}{$\begin{array}{c}\text { Subsample } \\
\text { type }\end{array}$} & \multirow{2}{*}{$\begin{array}{l}\text { Total } \\
\text { No. }\end{array}$} & \multicolumn{3}{|c|}{ Infestation } \\
\hline & & Positive & Suspected & Negative \\
\hline $\begin{array}{l}\text { Dockage ... } \\
\text { Wheat }\end{array}$ & 110 & 27 & 45 & 38 \\
\hline kernels. & 393 & 393 & $\cdots$ & $\ldots$ \\
\hline
\end{tabular}

Table 3.-Visual inspection of samples after 9-week rearing period

\begin{tabular}{rrrrr}
\hline \multirow{2}{*}{$\begin{array}{c}\text { Sample } \\
\text { Nos. }\end{array}$} & Total & Infested & \multicolumn{2}{c}{ Emerged } \\
\cline { 4 - 5 } & & & Live & Dead \\
\hline $1-141$ & 138 & 122 & 43 & 79 \\
$142-600$ & 459 & 337 & 257 & 80 \\
$1-600$ & 597 & 459 & 300 & 159 \\
\hline
\end{tabular}

${ }^{1}$ Sample Nos. 22, 23, and 126 were missing.

Table 4.-Insect species ${ }^{1}$ identified in wheat samples

\begin{tabular}{|c|c|c|c|c|c|c|c|c|c|}
\hline \multirow[b]{2}{*}{ Month and year } & \multirow[b]{2}{*}{$\begin{array}{c}\text { Total } \\
\text { samples } \\
\text { per } \\
\text { month }\end{array}$} & \multicolumn{8}{|c|}{ Number of wheat samples infested with- } \\
\hline & & $\begin{array}{c}\text { Rice } \\
\text { weevil }\end{array}$ & $\begin{array}{c}\text { Lesser } \\
\text { grain } \\
\text { borer }\end{array}$ & $\begin{array}{l}\text { Flat } \\
\text { grain } \\
\text { beetle }\end{array}$ & $\begin{array}{l}\text { Saw- } \\
\text { toothed } \\
\text { grain } \\
\text { beetle }\end{array}$ & Moth & Weevil & $\begin{array}{l}\text { Grain } \\
\text { beetle }\end{array}$ & Other ${ }^{2}$ \\
\hline \multicolumn{10}{|l|}{1977} \\
\hline October .............. & 19 & 5 & 11 & 1 & $\ldots \ldots$ & 7 & 7 & 2 & 2 \\
\hline November ${ }^{3} \ldots \ldots \ldots \ldots$ & 31 & 9 & 10 & 1 & 1 & 11 & 15 & 1 & 12 \\
\hline $\begin{array}{c}\text { December } \ldots \ldots \ldots \ldots \\
1978\end{array}$ & 46 & 23 & 15 & $\ldots \ldots \ldots$ & 1 & 14 & 2 & $\ldots \ldots \ldots$ & 5 \\
\hline January $^{4} \ldots \ldots \ldots \ldots$ & 30 & 20 & 20 & 9 & . & 7 & .. & $\ldots$ & 2 \\
\hline February ............ & 26 & 18 & 11 & 1 & $\ldots \ldots$ & 3 & $\ldots \ldots$ & $\ldots \ldots \ldots$ & . \\
\hline March .............. & 10 & 6 & 1 & $\ldots \ldots$ & $\ldots \ldots$ & 3 & $\ldots \ldots$ & 1 & 1 \\
\hline April $\ldots \ldots \ldots \ldots \ldots$ & 75 & 37 & 16 & 3 & 1 & 4 & 17 & 3 & 1 \\
\hline 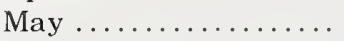 & 41 & 22 & 14 & $\ldots \ldots$ & $\ldots \ldots$ & 9 & 9 & 3 & $\ldots \ldots$ \\
\hline June . . . . . . . . . . . & 60 & 22 & 17 & $\ldots \ldots$ & 4 & 5 & 8 & 4 & 6 \\
\hline July .............. & 30 & 8 & 12 & $\ldots \ldots$ & $\ldots \ldots$ & 9 & 7 & 1 & 8 \\
\hline August .............. & 36 & 17 & 16 & $\ldots \ldots \ldots$ & 4 & 9 & 4 & $\ldots \ldots$ & 9 \\
\hline September .......... & 35 & 14 & 23 & 10 & $\ldots \ldots$ & 5 & 6 & 2 & 8 \\
\hline October ............. & 47 & 25 & 37 & 11 & 3 & 13 & 9 & 2 & 9 \\
\hline November ........... & 23 & 9 & 16 & 6 & 2 & 10 & 4 & 2 & 1 \\
\hline $\begin{array}{c}\text { December } \ldots \ldots \ldots \ldots \ldots \\
1979^{5}\end{array}$ & 11 & 3 & 6 & 3 & 4 & 9 & 2 & $\ldots \ldots \ldots$ & 5 \\
\hline March .............. & 58 & 24 & 25 & 3 & $\ldots$ & 2 & 12 & 3 & 14 \\
\hline April $\ldots \ldots \ldots \ldots \ldots$ & 19 & 9 & 5 & 2 & $\ldots \ldots \ldots$ & 1 & 6 & 3 & 5 \\
\hline Total & 597 & 271 & 255 & 50 & 20 & 121 & 108 & 27 & 88 \\
\hline
\end{tabular}

'Rice weevil, Sitophilus oryzae (Linnaeus); lesser grain borer, Rhyzopertha dominica (Fabricius); flat grain beetle, Cryptolestes pusillus (Schönherr); sawtoothed grain beetle, Oryzaephilus surinamensis (Linnaeus). Moths were Indian meal moth, Plodia interpunctella (Hübner); Angoumois grain moth, Sitotroga cerealella (Olivier); and Mediterranean flour moth, Anagasta kuehniella (Zeller); moths usually could not be identified because of their fragmented condition. Weevils were granary weevil, Sitophilus granarius (Linnaeus), and maize weevil, Sitophilus zeamais Motschulsky; weevils usually could not be identified because of their fragmented condition. Grain beetles were merchant grain beetle, Oryzaephilus mercator (Fauvel); squarenecked grain beetle, Cathartus quadricollis (Guérin-Méneville); and foreign grain beetle, Ahasverus advena (Waltl).

${ }^{2}$ Includes black carpet beetle, Attagenus megatoma (Fabricius); cigarette beetle, Lasioderma serricorne (Fabricius); confused flour beetle, Tribolium confusum Jacquelin du Val; red flour beetle, Tribolium castaneum (Herbst); corn sap beetle, Carpophilus dimidiatus (Fabricius); mites, Tyrophagus spp. and Acarus sp.; and unidentifiable insect parts.

${ }^{3}$ No. 126 was missing.

${ }^{4}$ Nos. 22 and 23 were missing.

${ }^{5}$ No samples taken in January 1979 or February 1979 because of lack of technician help. 
and in how much X-rays penetrated each. Analysis of radiographs of wheat kernels was equally as time consuming but more definitive.

\section{INSECT REARING}

Results of the visual inspection of samples after the 9-week rearing period revealed that $77 \%$ of the 597 samples had evidence of emergence (adult insects) and were therefore considered infested (table 3). Examination of samples 1-141 revealed 79 samples that had been infested, but all emerged adults were dead. The high percentage (65\%) of such samples probably resulted because lack of enough technicians caused many samples to be inspected several months after the scheduled time; so the insects had starved after eating all available food.

More than 10 insect species and 1 mite species were identified (table 4). Samples were collected from October 1977 through April 1979; only in 1978 are data available for all 12 months of the year. But, because of equipment and support problems in March 1978 and December 1978, relatively few samples were received for those months.

\section{DISCUSSION}

The results indicate that $\mathrm{IR} \mathrm{CO}_{2}$ analysis and the instrumentation tested are significantly better than present FGIS standard procedures at detecting hidden insect infestations. This better performance is understandable since IR $\mathrm{CO}_{2}$ analysis is able to detect $\mathrm{CO}_{2}$ emitted both from individual insects that have emerged from the kernels of grain and from those that are concealed and developing in the kernel. Of course, it would be difficult for IR $\mathrm{CO}_{2}$ analysis to detect, for example, one insect egg or one sawtoothed grain beetle in a 1,000-g grain sample in the time allowed by current inspection procedures. But such pinpoint detection would be possible if the inspection procedures were changed to allow the extra time needed (Street and Bruce 1976b). Even if the baseline of $\mathrm{CO}_{2}$ sensitivity were raised to correspond only to levels of $\mathrm{CO}_{2}$ considerably higher than those produced by one insect (for example, $\mathrm{CO}_{2}$ produced by 50 rice weevils in 5 minutes), the detection capability would still be superior to current standards. And decreasing the sensitivity would increase the ratio of signal to noise (electrical), which would in turn increase the overall stability of the system.

The second objective of the study was to determine if dockage would alter the effectiveness of the detection system. There was no indication that dockage would interfere with the detection capability of the system. But frequent or excessive dockage would require a more frequent change of inline dust filters. And removal of dockage to be inspected separately did cause some concern at the Savannah laboratory. Because the volume of dockage present in each sample may vary, the dockage-sample container should be able to conform to these differences to eliminate excessive interstitial airspace. This potential problem was apparently corrected by putting the dockage in a Nitex bag and placing it in a standard test chamber filled with an inert material (glass beads). So the wheat sample and dockage were inspected in the same test chamber with essentially the same interstitial air volume. Of course, in a normal inspection routine, the dockage would not be separated but niould be inspected with the wheat kernels.

The third objective of the study was to determine if the results from detection units would be about the same. Results with similar analyzers were, in fact, similar overall. Other than MSA analyzer No. 1 having had, on occasion, slightly more electrical background noise than MSA No. 2, both performed equally well. The two Horiba analyzers performed similarly overall but did not always give the same result for a particular sample. That samples were inspected first in Houston and then several days later in Savannah also made interpretation and comparison of data somewhat difficult. For instance, a given population would be older when it arrived in Savannah and might therefore be expected to have a higher output of $\mathrm{CO}_{2}$. But more individuals may have reached the pupal stage, a factor that would tend to lower the $\mathrm{CO}_{2}$ output. Or the population may have been alive in Houston but dead when the sample reached Savannah, and subsequent inspection might detect a limited quantity of residual or entrained insect-produced $\mathrm{CO}_{2}$ still in the kernel. Also, the population could have died sometime during the Savannah rearing period. These possibilities may explain thoseinstances 
where infestations were detected in samples having no living insects (table 1).

The X-ray radiographs taken of samples after the 9-week rearing period supported the effectiveness of IR $\mathrm{CO}_{2}$ analysis. Interpretation of the radiographs was sometimes difficult. But they did indicate that $91 \%$ of the nonpositive (Savannah Horiba), nonemerged samples that were X-rayed had been infested, though the insects had died. Both Technicon Horiba and Savannah Horiba detected live infestations in more than $80 \%$ of the samples. And, though further analysis (rearing and X-ray) showed that most of the nonpositive samples had, in fact, been infested, IR $\mathrm{CO}_{2}$ analysis is far more effective than current routine inspection procedures. And it is far less costly and time consuming than insect rearing and X-ray analysis.

As the world demand for quality food, feed, seed, and fiber increases, the need to insure this quality against insect attack becomes even more important. The results of this study indicate the potential of IR $\mathrm{CO}_{2}$ analysis to detect hidden insect infestations throughout the marketing channel. Clearly, this system could be successfully incorporated into an FGIS inspection routine if appropriate changes were made in the current inspection standards (for example, inclusion of immature stages of insects). Present studies also suggest that the greatest potential of the system may be to monitor for insects in the vast bulk storage of grain held throughout the United States, therefore helping maintain grain quality for both domestic and foreign markets.

\section{REFERENCES}

Adams, R. E.; Wolfe, J. E.; Milner, M.; and Shellenberger, J. A.

1954. Detection of internal insect infestation in grain by sound amplification. Cereal Chem. 31: 271-276.

Bruce, W. A., and Street, M. W., Jr.

1974. Infrared $\mathrm{CO}_{2}$ detection of hidden insects. J. Ga. Entomol. Soc. 9: 260-265.

1975. A technique for monitoring living organisms. Proc. Int. Conf. Int. Soc. Chronobiology, 12th, pp. 627-629.

1979. The use of electromagnetic energy to detect hidden insect infestation. Proc. Int. Work. Conf.
Stored-Product Entomol. 2d, pp. 230-236.

Bruce, W. A.; Street, M. W.; and Kvenberg, J. E.

1978. Potential use of infrared devices for detecting hidden insects. FDA By-Lines 1: 10-15.

Dennis, N. M., and Decker, R. W.

1962. A method and machine for detecting living internal infestation in wheat. J. Econ. Entomol. 55: 199-203.

Milner, M.

1958. New methods to detect and eliminate insectinfested grain. In E.M. Mrak and C. F. Stewart (eds.), Advances in Food Research, pp. 111-131. Academic Press, New York.

Street, M. W., Jr., and Bruce, W. A.

1976a. $\mathrm{CO}_{2}$ analyzer detects insects hidden in foods. Food Eng. 48 (2): 94, 96.

1976b. Hidden-insect detection by infrared carbon dioxide gas analysis. Principles of system design. U.S. Agric. Res. Serv. [Rep.]ARS-S-85, $10 \mathrm{pp}$. (Available from the Stored-Product Insects Research and Development Laboratory, P.O. Box 22909, Savannah, Ga. 31403.)

\section{APPENDIX.-SUPPLIER NAMES AND ADDRESSES}

Beckman Instruments

Fullerton, Calif.

Dwyer

Michigan City, Ind.

E\&K Scientific Products

Saratoga, Calif.

Hewlett-Packard

McMinnville, Oreg.

Horiba Instruments

Irvine, Calif.

Industrial Timer Corp.

Parsippany, N.J.

Kodak-Eastman Kodak Rochester, N.Y.

Mine Safety Appliances

Pittsburgh, $\mathrm{Pa}$.

Nitex-Tobler, Ernst, and Traber Elmsford, N.Y.

Technicon Instruments Corp.

Tarrytown, N.Y.

Universal Electric Co.

Owosso, Mich. 



U. S. DEPARTMENT OF AGRICULTURE AGRICULTURAL RESEARCH SERVICE

SOUTHERN REGION

P. O. BOX 53326

NEW ORLEANS, LOUISIANA 70153

OFFICIAL BUSINESS

PENALTY FOR PRIVATE USE, \$300

POSTAGE AND FEES PAID

U. S. DEPARTMENT OF AGRICULTURE

AGR 101

FIRST CLASS 